\title{
Myxobolus pseudowulii sp. n. (Myxozoa: Myxosporea), a new skin parasite of yellow catfish Tachysurus fulvidraco (Richardson) and redescription of Myxobolus voremkhai (Akhmerov, 1960)
}

\author{
Bo Zhang ${ }^{1,2}$, Yanhua Zhai ${ }^{1,2,3}$, Yang Liu ${ }^{1,2,3}$ and Zemao Gu ${ }^{1,2,3}$ \\ ${ }^{1}$ Department of Aquatic Animal Medicine, College of Fisheries, Huazhong Agricultural University, Wuhan, People's Republic of \\ China; \\ ${ }^{2}$ Key Lab of Freshwater Animal Breeding, Ministry of Agriculture, Wuhan, People's Republic of China; \\ ${ }^{3}$ Hubei Engineering Research Center for Aquatic Animal Diseases Control and Prevention, Wuhan, People's Republic of China
}

\begin{abstract}
Two species of Myxobolus Bütschli, 1882 were found in yellow catfish Tachysurus fulvidraco (Richardson). A species of Myxobolus infecting the gills was morphologically identified as Myxobolus voremkhai (Akhmerov, 1960) and it was characterised here with additional morphological and molecular data. The other species of Myxobolus infecting the host's skin did not conform to any known myxosporean species. It is characterised by the presence of round, black or milky white plasmodia with black spots. Myxospores are pyriform in frontal view and lemon-shaped in lateral view, measuring $12.9-16.2 \mu \mathrm{m}(14.6 \pm 0.7 \mu \mathrm{m})$ in length, $8.1-10.8 \mu \mathrm{m}$ $(9.4 \pm 0.5 \mu \mathrm{m})$ in width, and 6.1-8.1 $\mu \mathrm{m}(7.0 \pm 0.4 \mu \mathrm{m})$ in thickness. Two ampullaceous polar capsules are slightly unequal in size, larger polar capsule 7.2-9.5 $\mu \mathrm{m}(7.9 \pm 0.4 \mu \mathrm{m})$ long by 3.0-3.9 $\mu \mathrm{m}(3.5 \pm 0.2 \mu \mathrm{m})$ wide, smaller capsule $6.9-8.0 \mu \mathrm{m}(7.4 \pm 0.3 \mu \mathrm{m})$ long by $2.9-3.9 \mu \mathrm{m}(3.4 \pm 0.2 \mu \mathrm{m})$ wide. Polar filaments are coiled with seven to nine turns. Histologically, the plasmodia develop in the stratum spongiosum of skin dermis, resulting in epithelial cell shedding and immunological cell infiltration. Given the morphological and molecular differences between this species and other species of Myxobolus, we proposed the name of Myxobolus pseudowulii sp. n. for this parasite from the skin of yellow catfish. Interestingly, some spores of the new species possess Henneguya-like caudal appendages. Phylogenetically, M. pseudowulii sp. n. and M. voremkhai infecting yellow catfish group together in one clade with other parasites of Siluriformes, indicating that parasites clustering according to the fish host order may be an important factor affecting the evolution of species within the Myxobolus clade.
\end{abstract}

Keywords: phylogeny, morphology, histology, ssrRNA, China

Myxosporeans are an economically important microscopic metazoan endoparasites infecting mainly fish and infrequently amphibians, reptiles, birds and mammals (Lom and Dyková 2006, Fiala et al. 2015). Owing to their negative impact on fish, myxosporeans have attracted much attention (Lom and Dyková 2006, Liu et al. 2010a, Fiala et al. 2015, Velasco et al. 2016). To date, approximately 2,300 myxosporean species have been described based on spore morphology (Fiala et al. 2015). However, due to incredible species diversity and uniformity of spores, which are used for species identification, distinguishing the morphologically similar species based on spore morphology alone has resulted in misidentification of several cryptic species in the past (Lom and Dyková 2006, Liu et al. 2010b, 2011, 2013, Fiala et al. 2015). In China, several morphologically similar myxosporean species infecting different tissues and organs of different hosts were misidentified as the same species (Chen and Ma 1998). Therefore, it is crucial to validate the already described myxosporean species and identify cryptic and new myxosporean species by combination of spore morphology, biological traits (host species/family specificity, organ specificity, tissue tropism), and molecular data (Liu et al. 2014a, Thabet et al. 2016, Velasco et al. 2016).

Yellow catfish Tachysurus fulvidraco (Richardson) (Siluriformes: Bagridae) is an economically important fish cultured in China with an annual production over 300 million kilograms (Fishery Bureau in Ministry of Agricultural 2016). According to Chen and Ma (1998), approximately 24 myxosporeans have been found from different tissues and organs of yellow catfish in China. Although most of the species do not cause severe diseases, several species have been reported as serious pathogens responsible for mass mortality or loss of economic value of yellow cat- 
fish (Chen and Ma 1998), such as Unicauda pelteobagrus Ma, 1998 infecting the gills, and Myxidium pseudobagrusi Chen et Hsieh, 1984 infecting the kidney.

An investigation was conducted on the myxosporean diversity of yellow catfish. Here, we report a novel species of Myxobolus Bütschli, 1882 infecting the skin of yellow catfish and rediscribe Myxobolus voremkhai (Akhmerov, 1960) infecting the gills of this fish host.

\section{MATERIALS AND METHODS}

\section{Fish samples}

One yellow catfish (18.0 cm in length) collected from a fish farm in Yingcheng City, Hubei Province, with several plasmodia (cysts) in the skin and gills was transported to the Laboratory of Fish Diseases in College of Fisheries, Huazhong Agricultural University, Wuhan, Hubei Province, China in June 2016. The fish was held in aquaria in the laboratory and euthanised with $0.2 \mathrm{mg} /$ $\mathrm{ml}$ tricaine methanesulfonate (MS-222, Sigma, St. Louis, MO, USA) prior to dissection.

\section{Morphological methods}

Gross microscopic examinations of the organs of yellow catfish for myxosporean infections were conducted within $24 \mathrm{~h}$ after its transportation. The plasmodia containing myxospores consistent with those of species of the genus Myxobolus were collected from the skin and gills. Fresh spores were measured as reported by Lom and Arthur (1989) using an Olympus BH2 microscope equipped with an ocular micrometre. Mean and standard deviations of each spore dimension were obtained from fresh mature spores $(n=60)$. Digitised images were obtained from fresh wet mounts by a Nikon Eclipse $80 \mathrm{i}$ microscope. Line drawings were made based on digitised images. All measurements are given in micrometres $(\mu \mathrm{m})$ unless otherwise indicated.

\section{Histological observation}

Tissue samples from organs containing developing and mature plasmodia were fixed in Bouin's solution, embedded in paraffin wax, sectioned at 5-6 $\mu \mathrm{m}$ and stained with haematoxylin and eo$\sin$.

\section{DNA isolation and sequencing}

Genomic DNA was extracted using BioTeke ${ }^{\mathrm{TM}}$ Genomic DNA extraction kit (BioTeke Co., Ltd., Beijing, China) according to the manufacturer's protocol. PCR amplification of the small subunit ribosomal RNA (ssrRNA) gene was performed with primers $18 \mathrm{e}$ of Hillis and Dixon (1991) and 18r of Whipps et al. (2003) in a $50 \mu \mathrm{l}$ volume of reaction solution, which consisted of approximately 100 ng of extracted genomic DNA, $1 \times$ Taq Buffer (MBI Fermentas, Vilnius, Lithuania), 2.5mM $\mathrm{MgCl}_{2}, 0.2 \mathrm{mM}$ dNTPs (MBI Fermentas), $2 \mu \mathrm{M}$ each primer, and $2.5 \mathrm{U}$ of Taq DNA polymerase (MBI Fermentas) in MilliQ purified water. The cycling conditions were as follows: an initial denaturation at $94^{\circ} \mathrm{C}$ for $7 \mathrm{~min}$, followed by 35 cycles of $94^{\circ} \mathrm{C}$ for $45 \mathrm{~s}, 55^{\circ} \mathrm{C}$ for $45 \mathrm{~s}$, and $72{ }^{\circ} \mathrm{C}$ for $60 \mathrm{~s}$, and a terminal extension at $72^{\circ} \mathrm{C}$ for $10 \mathrm{~min}$. PCR products were purified using the AxyPrep ${ }^{\mathrm{TM}}$ DNA Gel Extraction Kit (AxyGen Bio Co., Ltd., Hangzhou, China) and cloned into PMD-19T vector system (Takara, Otsu, Japan). Then two positive clones were selected and sequenced in both directions on the

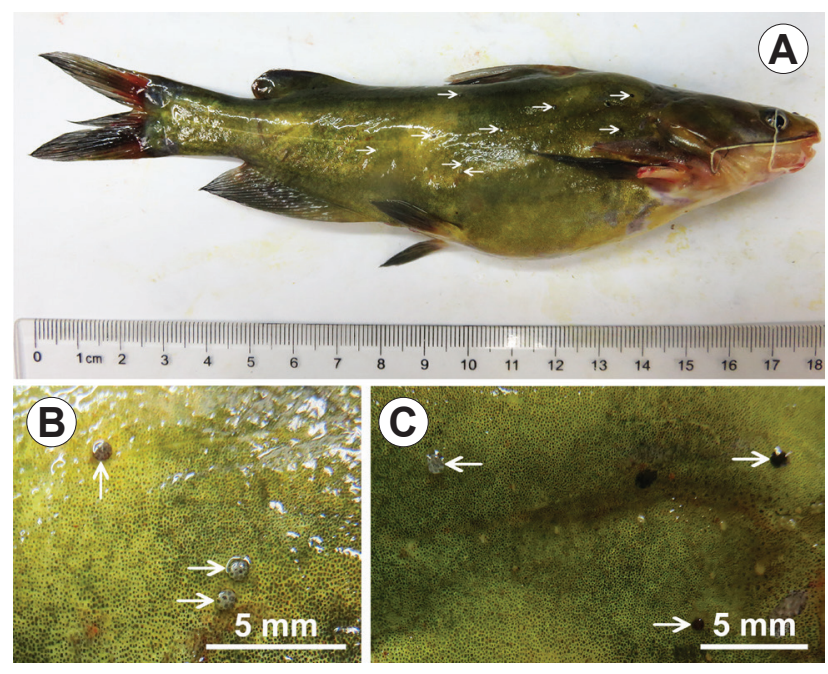

Fig. 1. Yellow catfish Tachysurus fulvidraco (Richardson) infected with Myxobolus pseudowulii sp. n. in the skin. Arrows show the plasmodia in the skin.

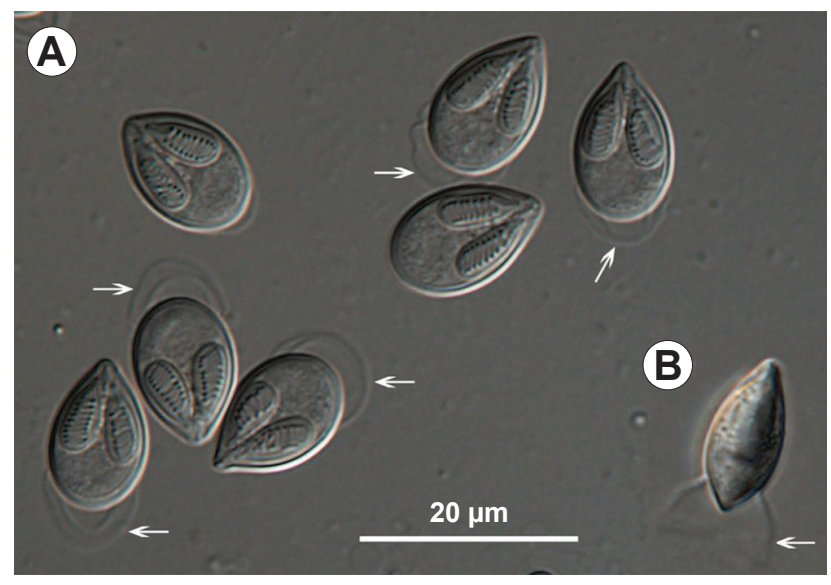

Fig. 2. Photomicrograph of fresh spores of Myxobolus pseudowulii sp. n. from Tachysurus fulvidraco (Richardson). A - frontal view; B - lateral view. Arrows show the membrane sheath.

ABI PRISM ${ }^{\circledR} 3730 X L$ DNA sequencer (Applied Biosystems Inc., Foster City, CA, USA). Forward and reverse sequence segments were aligned in BioEdit (Hall 1999) and a contiguous sequence was deposited in GenBank. A standard nucleotide-nucleotide BLAST search was conducted to query posted sequences.

\section{Phylogenetic analysis}

To evaluate the relationship of the current species to myxobolids available in GenBank, 52 sequences matching the top BLAST hits were aligned using the software MAFFT v. 7.271 with default parameters (Katoh and Standley 2013). Myxidium cuneiforme Fujita, 1924 was designated as outgroup. Phylogenetic analyses were carried out on 1,185 character alignment. Optimal evolutionary models for maximum likelihood (ML) and Bayesian analyses were determined by jModeltest (Posada 2008) using the Akaike information criterion as the general time reversible model $(\mathrm{GTR}+\mathrm{I}+\mathrm{G})$. Nucleotide frequencies were estimated from the data $(A=0.2935, C=0.1795, G=0.2639, T=0.2632)$; six rates of nucleotide substitution were $[\mathrm{AC}]=1.0145,[\mathrm{AG}]=3.6442$, $[\mathrm{AT}]=1.9003,[\mathrm{CG}]=0.6191,[\mathrm{CT}]=5.6391,[\mathrm{GT}]=1.0000$; 



Fig. 3. Line drawing of fresh spores of Myxobolus pseudowulii sp. n. from Tachysurus fulvidraco (Richardson).

the proportion of invariable sites was 0.3070 , and the gamma distribution was 0.5490 as estimated with six rate categories. ML analysis was performed using PhyML v. 3.1 (Guindon et al. 2010). Bootstrap confidence values were calculated with 1,000 replicates. Bayesian analysis was conducted in MrBayes (Ronquist and Huelsenbeck 2003) under an evolutionary model, with $10^{6}$ generations, tree sampled every 100 generations and the first $25 \%$ of trees was discarded as burn-in as analysed by the Tracer v 1.6 (Drummond and Rambaut 2007). Trees were initially examined in Figtree v.1.4.3 (Drummond and Rambaut 2007), then edited and annotated in Adobe Illustrator (Adobe Systems Inc., San Jose, CA, USA).

\section{RESULTS}

\section{Myxobolus pseudowulii sp. n.}

Figs. 1-4

ZooBank number for species:

urn:1sid:zoobank.org:act:ACAA06F7-15E0-49B8-97D4-28F910E86184

Description. Plasmodia round, black or milky white with black spots, 0.65-1.09 $\mathrm{mm}$ in diameter. Histozoic in skin (Fig. 1). Myxospores (Figs. 2, 3) pyriform in frontal view and lemon shaped in lateral view, 12.9-16.2 (14.6 \pm 0.7$)$ long, 8.1-10.8 (9.4 \pm 0.5$)$ wide and 6.1-8.1 $(7.0 \pm 0.4)$ thick. Most spores surrounded by oval membrane sheath. Two ampullaceous polar capsules slightly unequal in size, with larger polar capsule 7.2-9.5 (7.9 \pm 0.4$)$ long by $3.0-3.9(3.5 \pm 0.2)$ wide, and smaller capsule 6.9-8.0 (7.4 \pm 0.3$)$ long by 2.9-3.9 (3.4 \pm 0.2$)$ wide. Polar filaments coiled with 7-9 turns. Sutural line straight and distinct (Fig. 3). Some spores with caudal appendages 2.2-4.5 long (Fig. 4).

Histology. The plasmodia of Myxobolus pseudowulii sp. n. developed in the stratum spongiosum of skin dermis (Fig. 7A), which contained the spores and some late developmental stages (Fig. 7B). A number of melanocytes were observed to surround the plasmodia (Fig. 7B,C). This
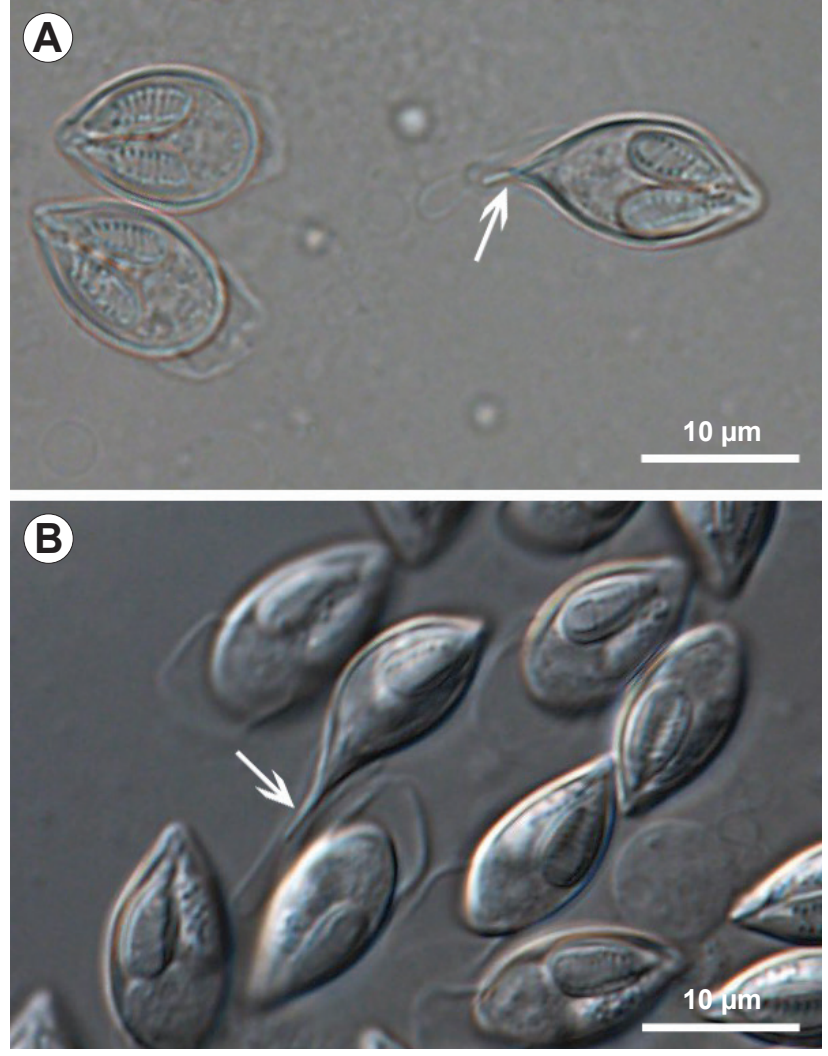

Fig. 4. Photomicrograph of spores of Myxobolus pseudowulii sp. $\mathrm{n}$. with caudal appendages (arrows) from Tachysurus fulvidraco (Richardson).

infection resulted in epithelial cells shedding of the skin and the inflammatory responses of immunological cell infiltration were also observed (Fig. 7D).

Type host: Yellow catfish Tachysurus fulvidraco (Richardson) (Siluriformes: Bagridae).

Locality: Fish farm in Yingcheng City, Hubei, China $\left(30^{\circ} 55^{\prime} \mathrm{N} ; 113^{\circ} 34^{\prime} \mathrm{E}\right.$; June 2016$)$.

Site of infection: Skin.

Type material: Mature spores fixed in $5 \%$ formalin were deposited in National Zoological Museum of China, Institute of Zoology, Chinese Academy of Sciences (Coll. No. CFPM201603).

Etymology: The species is named for the similarity of its spore shape to that of Myxobolus wulii Landsberg et Lom, 1991.

Remarks. In terms of spore morphology, M. pseudowulii differed not only from all the species of Myxobolus infecting yellow catfish, but also from myxobolids from phylogenetically closely related fish species, albeit being morphologically similar to $M$. pfrille Landsberg et Lom, 1991, M. kiangsiensis Chen in Chen et Ma, 1998 and M. aureatus Ward, 1919 (Table 1). Oval spores of M. pfrille are different from those of M. pseudowulii in their shape. Myxobolus kiangsiensis can be distinguished from $M$. pseudowulii by its eggplant-like polar capsules. The polar capsules of $M$. aureatus are smaller than those of M. pseudowulii and the melon seed-like spore of $M$. $a u$ reatus are also different from those of the present species 


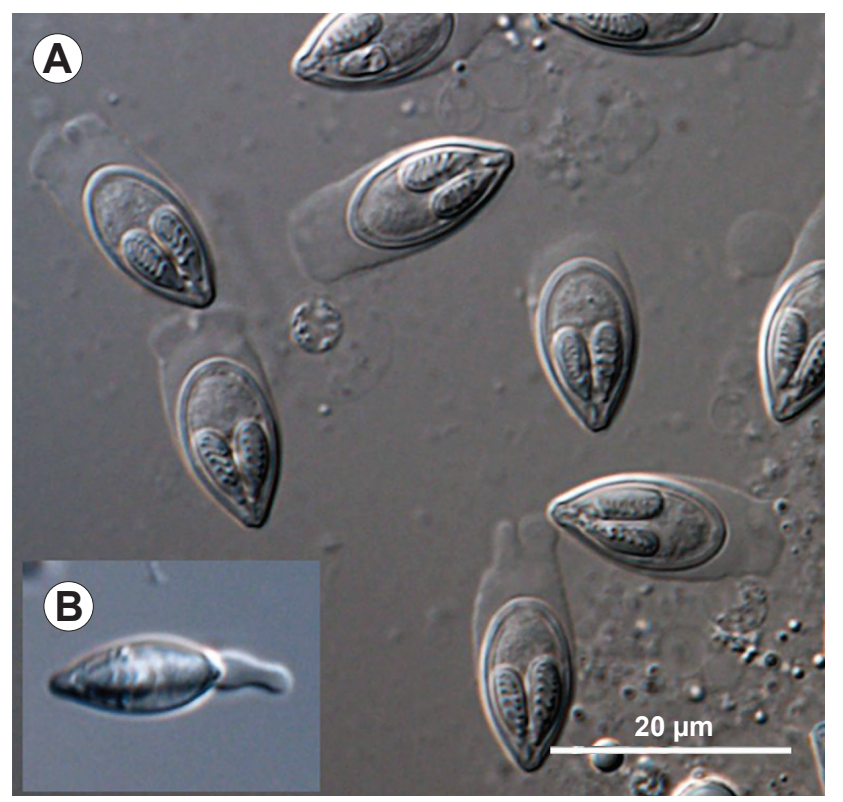

Fig. 5. Photomicrograph of fresh spores of Myxobolus voremkhai (Akhmerov, 1960) from Tachysurus fulvidraco (Richardson). A - frontal view; B - lateral view.
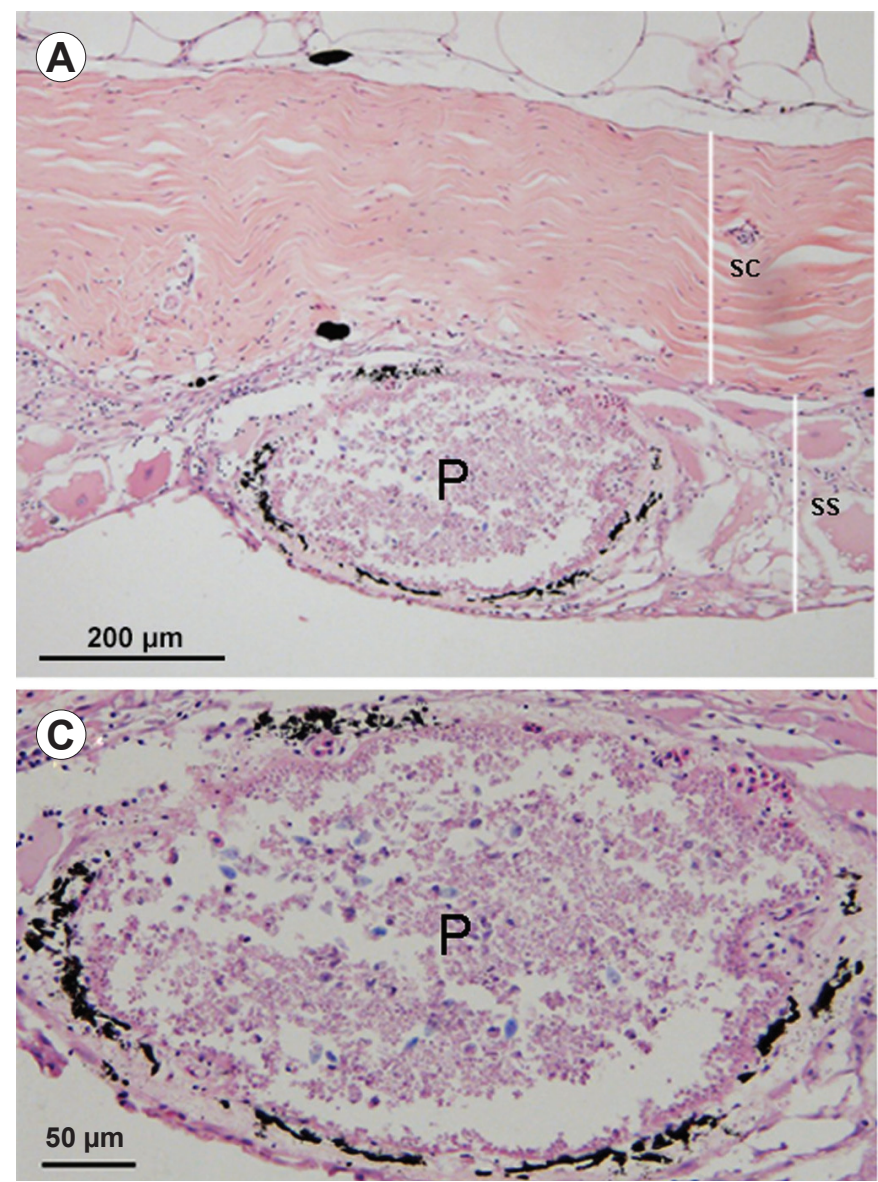
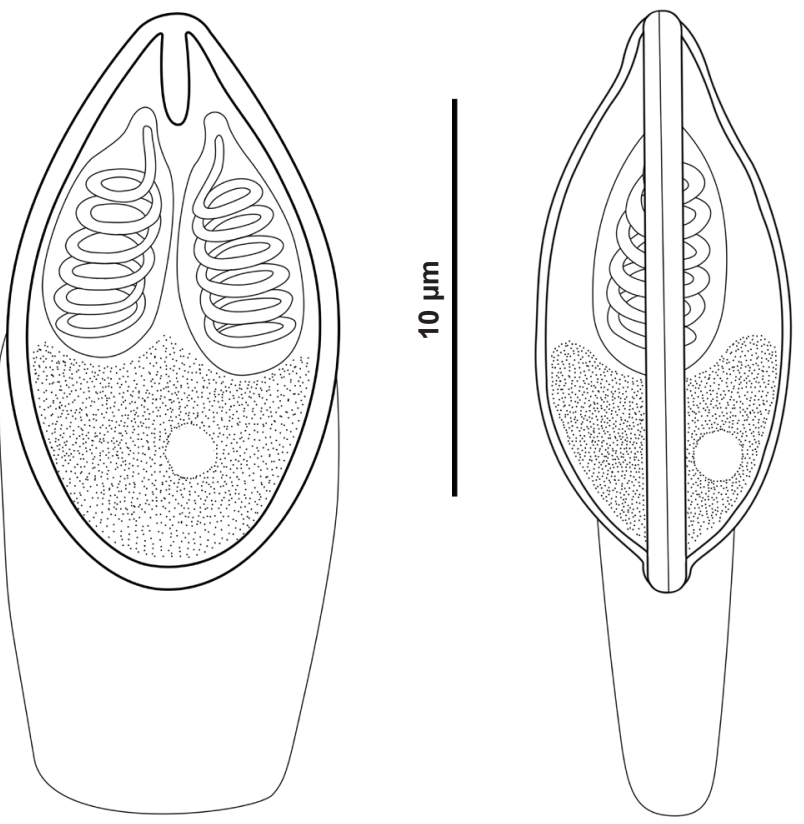

Fig. 6. Line drawing of fresh spores of Myxobolus voremkhai (Akhmerov, 1960) from Tachysurus fulvidraco (Richardson).

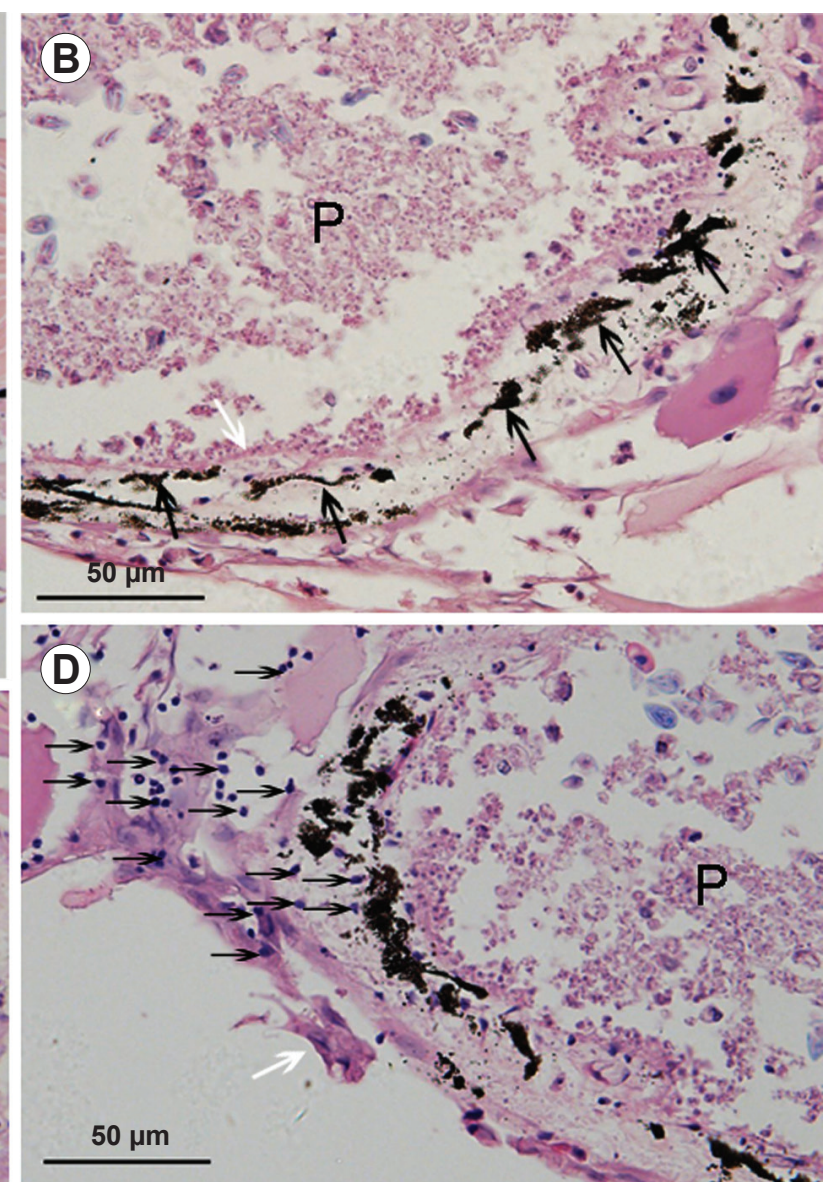

Fig. 7. Histology of skin with plasmodia of Myxobolus pseudowulii sp. n. from Tachysurus fulvidraco (Richardson). A - plasmodium developing in the stratum spongiosum of dermis; $\mathbf{B}, \mathbf{C}$ - number of melanocytes surrounding the plasmodium; black arrows show the melanocytes and white arrow shows the plasmodium membrane; D - epithelial cells shedding of the skin (white arrow) and lymphocytes (black arrows). Abbreviations: $\mathrm{P}$ - plasmodium; sc - stratum compactum; ss - stratum spongiosum. 


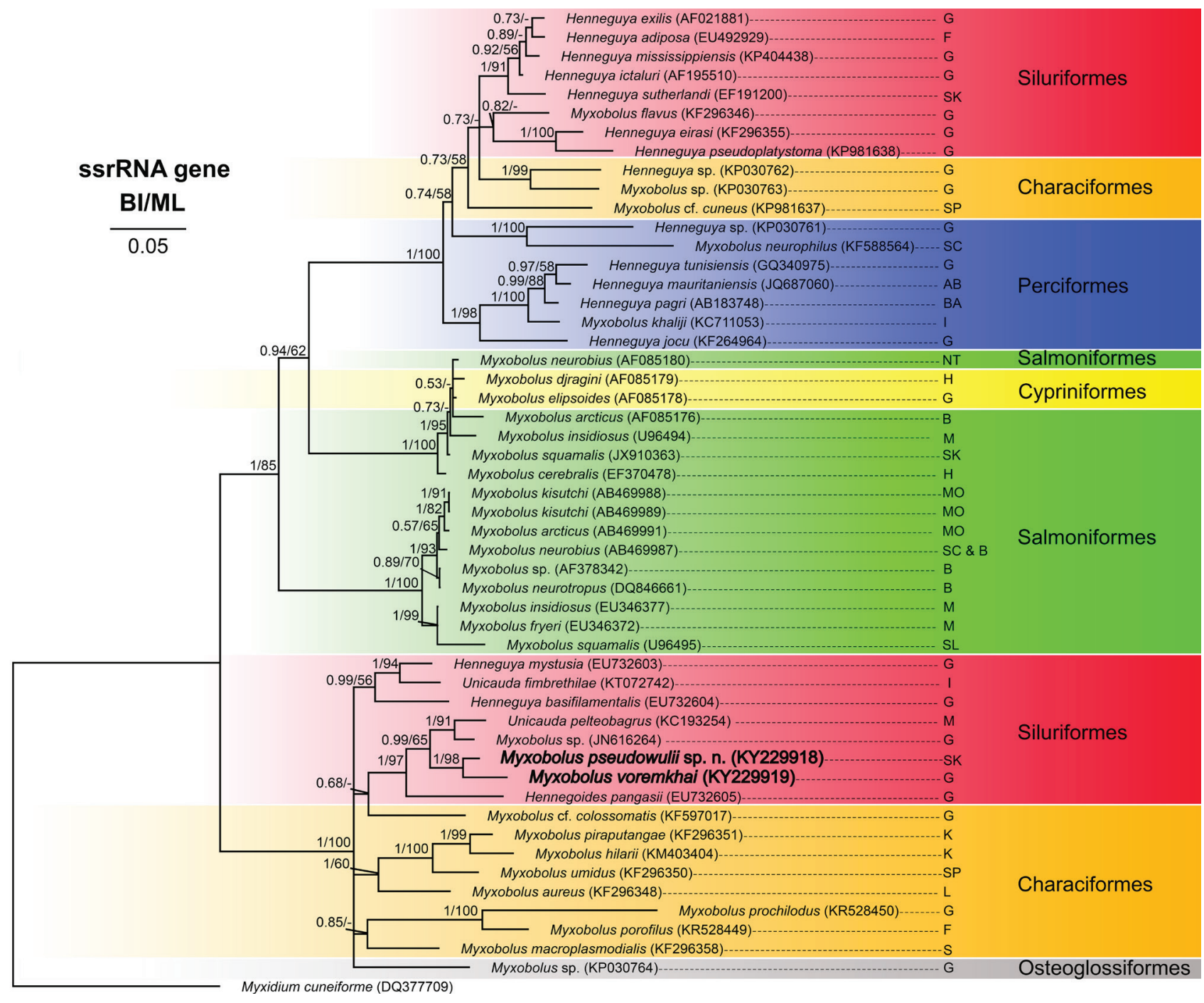

Fig. 8. Phylogenetic tree generated from Bayesian analysis of ssrRNA gene sequences of Myxobolus pseudowulii sp. n. and Myxobolus voremkhai Landsberg et Lom, 1991 and related myxobolids. GenBank accession numbers are listed adjacent to species names. Support values at branching points are listed as: Bayesian posterior probabilities/bootstrap values from maximum likelihood analysis. Dashes are shown for values under 50\%. Abbreviations: AB - arterial bulb; B - brain; BA - bulbus arteriosus; F - fins; $\mathrm{G}$ - gills; $\mathrm{H}$ - head; I - intestine; K - kidney; L - liver; M - muscle; MO - medulla oblongata; NT - neural tissue; S - serosa; SC - spinal cord; SK - skin; $\mathrm{SL}$ - scales; SP - spleen.

in spore shape. While molecular biological methods have become the mainstream in myxosporean species identification (Kaur and Attri 2015, Mansour et al. 2015, Özer et al. 2016), to our best knowledge, no molecular studies on M. pfrille, M. kiangsiensis, M. gigi (Fujita, 1927) and $M$. aureatus have been conducted to compare them molecularly with M. pseudowulii so far.

Myxobolus voremkhai (Akhmerov, 1960) Landsberg et Lom, 1991

Figs. 5, 6

\section{Syn.: Myxobolus pseudorasborae Akhmerov, 1960}

Redescription (based on material from China). One plasmodium oval, milky white, $0.86 \mathrm{~mm}$ in diameter. Histozoic in gills. Myxospores (Figs. 5, 6) elongated pyriform in frontal view, lemon-shaped in lateral view, 13.1-15.5 $(14.5 \pm 0.5)$ long, $7.1-8.6(7.8 \pm 0.3)$ wide and 5.6-7.2
$(6.3 \pm 0.4)$ thick. Most spores surrounded by approximately oblong membrane sheath with horizontally straight end. Two ampullaceous polar capsules, slightly unequal in size, with larger polar capsule 6.3-7.4 (6.8 \pm 0.3$)$ long by 2.2-3.3 $(2.8 \pm 0.2)$ wide, and smaller capsule 5.8-7.1 (6.5 \pm 0.3$)$ long by $2.2-3.3(2.8 \pm 0.2)$ wide. Polar filaments coiled with 5-7 turns. Sutural line straight and distinct (Fig. 6).

Histology not available.

Type host: Yellow catfish Tachysurus fulvidraco (Richardson) (Siluriformes: Bagridae).

Type locality: Amur River basin, Russia.

O the r loc ality: Fish farm in Yingcheng City, Hubei, China $\left(30^{\circ} 55^{\prime} \mathrm{N} ; 113^{\circ} 34^{\prime} \mathrm{E}\right.$; June 2016$)$.

Site of infection: Gills.

Voucher specimens: Mature spores fixed in 5\% formalin were deposited in National Zoological Museum of China, Institute of Zoology, Chinese Academy of Sciences with associated collection number CFPM201604. 


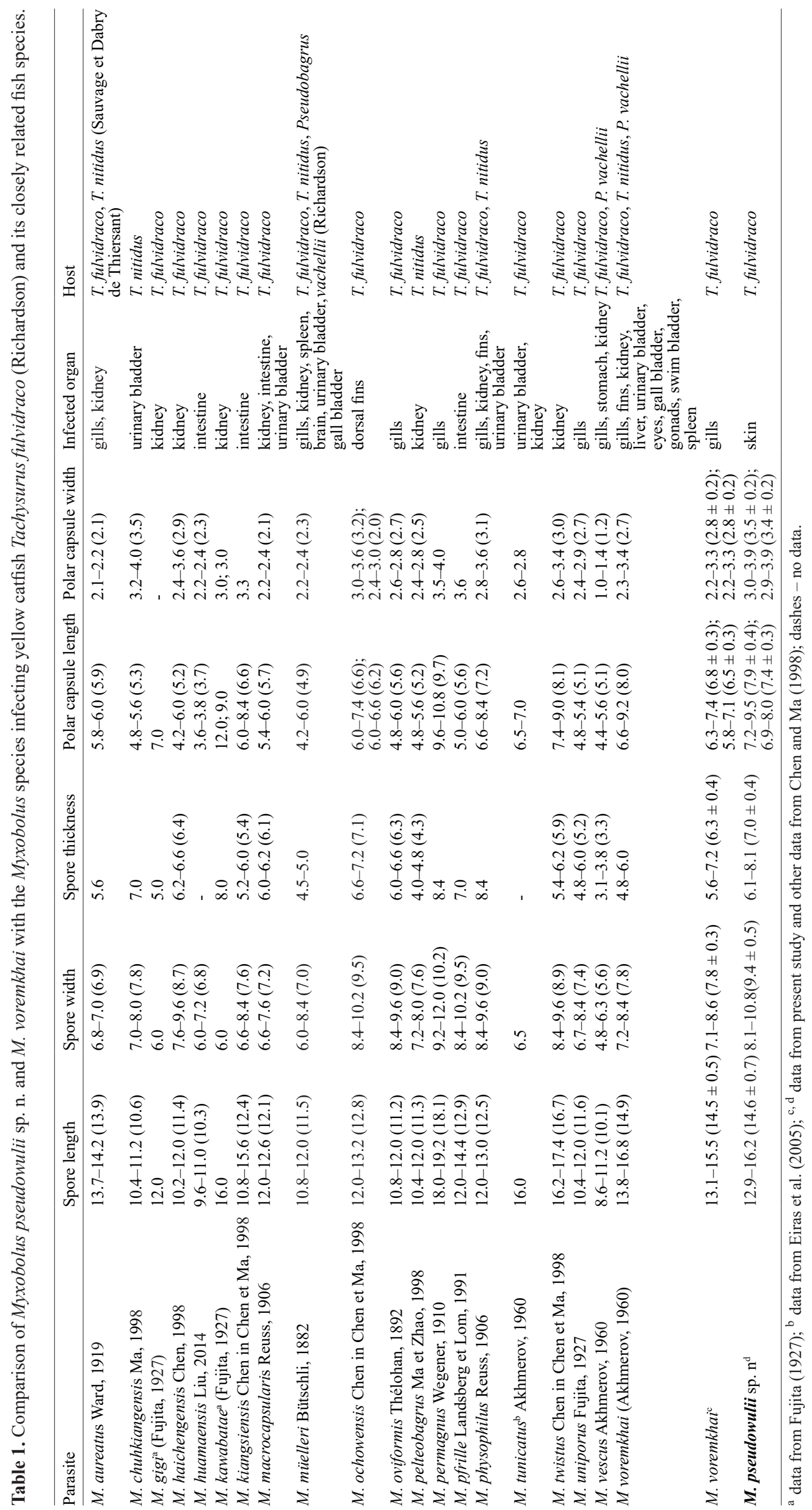


Remarks. In a morphological comparison with Myxobolus species infecting yellow catfish and its closely related fish species (Table 1), the present species could be distinguished from all of them by the size of myxospores except $M$. voremkhai. The present species is identical to M. voremkhai in morphological and morphometric characters. Moreover, the present species infecting the gills of yellow catfish is similar to the description of $M$. voremkhai (syn. Myxobolus pseudorasborae Akhmerov, 1960) in Chen and Ma (1998). Above all, despite the absence of comparable molecular data of $M$. voremkhai, the present species of Myxobolus can be identified as M. voremkhai. In addition, we supplement the molecular data on $M$. vorem$k h a i$ in the present research, which will facilitate its species identification in further research.

\section{Sequence analysis}

A total of 2,032 and 2,020 bases of the ssrRNA gene of Myxobolus pseudowulii sp. n. (KY229918) and Myxobolus voremkhai (KY229919) were generated, respectively, and the contiguous sequences were deposited in GenBank. A BLAST search indicated that both the ssrRNA gene sequences of $M$. pseudowulii and $M$. voremkhai did not match any available sequences in GenBank and they shared 92\% similarity with each other. ML and BI analyses resulted in congruent tree topologies with different nodal supports in certain cases. M. pseudowulii and M. voremkhai clustered together in the phylogenetic trees and were sisters to Myxobolus sp. (JN616264) and Unicauda pelteobagrus (KC193254) which all grouped within a mixed clade consisting of species of Myxobolus, Unicauda Davis, 1944 and Hennegoides Lom, Tonguthai et Dyková, 1991 (Fig. 8).

\section{DISCUSSION}

In the present paper, we presented morphological and molecular data for two species of Myxobolus from yellow catfish: Myxobolus pseudowulii sp. n. from the skin and Myxobolus voremkhai from the gills, which were identified based on spore morphology, biological traits, and molecular data. In the present study, the morphological and molecular analysis revealed that the species from the skin of yellow catfish is a novel species of Myxobolus. The species of Myxobolus infecting the gills of yellow catfish in the present paper is identified as $M$. voremkhai based on the identical morphology and infection site. Interestingly, the membrane sheath surrounding most $M$. voremkhai mature spores and some spores present in the plasmodium were not reported in its original species description (Akhmerov 1960). This membrane sheath variation was also reported in Thelohanellus wuhanensis Xiao et Chen, 1993 and Thelohanellus macrovacuolaris Liu, Zhai et Gu, 2016 (see Liu et al. 2014b, 2016). We speculate that different spore maturity might affect the existence of membrane sheath. Phylogenetic analyses placed $M$. pseudowulii and $M$. voremkhai in the mixed clade composed of species of the genera Myxobolus, Unicauda and Hennegoides. The non-monophyly of the genus Myxobolus has been reported many times to cluster some species from other genera into the Myxobolus clade, especially the species from the genus Henneguya Thélohan, 1892 characterised by the caudal appendages on the spores (Fiala 2006, Bartošová et al. 2009, Fiala and Bartošová 2010, Liu et al. 2010a).

Interestingly, some spores of Myxobolus pseudowulii with Henneguya-like caudal appendages were observed in the present study. Myxobolus spores with caudal appendages have been reported in several previous studies (Shulman 1966, Bahri 2008, El-Mansy 2005, Liu et al. 2010a, 2013, 2014a), indicating that species of Myxobolus have the genetic capacity to develop Henneguya-like caudal appendages, and the caudal appendages may not be a valid character to distinguish Myxobolus with Henneguya. Tissue tropism was found to be an important feature for general clustering of myxozoans (Fiala 2006, Carriero et al. 2013, Shin et al. 2014), but this trend was not observed for clustering of species within the Myxobolus clade in the present study. M. pseudowulii and $M$. voremkhai infecting the siluriform fish grouped together in one clade with other parasites of Siluriformes, indicating that the fish host order may be a more important factor that may have played a more important role in the evolution of species within the Myxobolus clade than tissue tropism.

Acknowledgements. This work was supported by the Nature Science Foundation of China (projects Nos. 31572233 and 31501848), Research and Demonstration of Key Techniques for High quality Aquatic Products (project No. 2016620000001046) and China Agriculture Research System (project No. CRAS-46).

\section{REFERENCES}

Akhmerov A.K. 1960: [Myxosporidia of fishes of the Amur River Basin.] Rybnoe Khozyaistvo Vodoemov Latv. SSR. 5: 239-308. (In Russian.)

BAHRi S. 2008: Abnormal forms of Myxobolus bizerti and Myxobolus mülleri (Myxosporea: Bivalvulida) spores with caudal appendages. Bull Eur. Assoc. Fish Pathol. 28: 252-255.

Bartošová P., Fiala I., HyPšA V. 2009: Concatenated SSU and LSU rDNA data confirm the main evolutionary trends within myxosporeans (Myxozoa: Myxosporea) and provide an effective tool for their molecular phylogenetics. Mol. Phylogenet. Evol. 53: 81-93.

Carriero M.M., Adriano E.A., Silva M.R.M., Ceccarelli P.A., Maia A.A.M. 2013: Molecular phylogeny of the Myxobolus and Henneguya genera with several new South American species. PLoS ONE 8: e73713.
Chen Q.L., Ma C.L. 1998: [Myxozoa: Myxosporea]. Science Press, Beijing, pp. 189-605. (In Chinese.)

Drummond A.J., Rambaut A. 2007: BEAST: Bayesian evolutionary analysis by sampling trees. BMC Evol. Biol. 7: 214.

Eiras J., Molnár K., Lu Y. 2005: Synopsis of the species of Myxobolus Bütschli, 1882 (Myxozoa: Myxosporea: Myxobolidae). Syst. Parasitol. 61: 1-46.

El-Mansy A. 2005: Revision of Myxobolus heterosporus Baker, 1963 (syn. Myxosoma heterospora) (Myxozoa: Myxosporea) in African records. Dis. Aquat. Organ. 63: 205-214.

Fiala I. 2006: The phylogeny of Myxosporea (Myxozoa) based on small subunit ribosomal RNA gene analysis. Int. J. Parasitol. 36: 1521-1534. 
Fiala I., BARTošová P. 2010: History of myxozoan character evolution on the basis of rDNA and EF-2 data. BMC Evol. Biol. 10: 228.

Fiala I., Bartošové-Sojková P., Whipps C.M. 2015: Classification and Phylogenetics of Myxozoa. In: B. Okamura, A. Gruhl and J.L. Bartholomew (Eds.), Myxozoan Evolution, Ecology and Development. Springer, Berlin, pp. 111-123.

Fishery Bureau in Ministry of Agriculture 2016: [China Fishery Statistics Yearbook]. China Agriculture Press, Beijing, pp. 36-41. (In Chinese.)

Fujita T. 1927: Studies on Myxosporidia of Japan. J. Coll. Agricult., Hokkaido Imperial Univ., Sapporo, Japan, 16: 229-247.

Guindon S., Dufayard J.F., Lefort V., Anisimova M., HordiJK W., Gascuel O. 2010: New algorithms and methods to estimate maximum-likelihood phylogenies: assessing the performance of PhyML 3.0. Syst. Biol. 59: 307-321.

Hall T.A. 1999: BioEdit: a user-friendly biological sequence alignment editor and analysis program for Windows 95/98/NT. Nucl. Acids Symp. Ser. 41: 95-98.

HiLlis D.M., Dixon M.T. 1991: Ribosomal DNA: molecular evolution and phylogenetic inference. Q. Rev. Biol. 66: 411-453.

Katoh K., Standley D.M. 2013: MAFFT multiple sequence alignment software version 7: improvements in performance and usability. Mol. Biol. Evol. 30: 772-780.

Kaur H., Attri R. 2015: Morphological and molecular characterization of Henneguya bicaudi n. sp. (Myxosporea: Myxobolidae) infecting gills of Cirrhinus mrigala (Ham.) in Harike Wetland, Punjab (India). Parasitol. Res. 114: 4161-4167.

Liv Y., Gu Z.M., Luo Y.L. 2010b: Some additional data to the occurrence, morphology and validity of Myxobolus turpisrotundus Zhang, 2009 (Myxozoa: Myxosporea). Parasitol. Res. 107: $67-73$.

Liv Y., Whipps C.M., Gu Z.M., Huang M.J., He C., Yang H.L., Molnar K. 2013: Myxobolus musseliusae (Myxozoa: Myxobolidae) from the gills of common carp Cyprinus carpio and revision of Myxobolus dispar recorded in China. Parasitol. Res. 112: 289-296.

Liu Y., Whipps C.M., Gu Z.M., Zeng L.B. 2010a: Myxobolus turpisrotundus (Myxosporea: Bivalvulida) spores with caudal appendages: investigating the validity of the genus Henneguya with morphological and molecular evidence. Parasitol. Res. 107: 699-706.

Liu Y., Whipps C.M., LiU W.S., Zeng L.B., Gu Z.M. 2011: Supplemental diagnosis of a myxozoan parasite from common carp Cyprinus carpio: synonymy of Thelohanellus xinyangensis with Thelohanellus kitauei. Vet. Parasitol. 178: 355-359.

LiU Y., WhipPs C.M., Nie P., Gu Z.M. 2014a: Myxobolus oralis sp. n. (Myxosporea: Bivalvulida) infecting the palate in the mouth of gibel carp Carassius auratus gibelio (Cypriniformes: Cyprinidae). Folia Parasitol. 61: 505-511.

Liu Y., Yuan J.F., Huang M.J., Jia L., Zhou Z.G., Gu Z.M. 2014b: Supplemental description of Thelohanellus wuhanensis
Xiao et Chen, 1993 (Myxozoa: Myxosporea) infecting the skin of allogynogenetic gibel carp Carassius auratus gibelio (Bloch). Parasitol. Int. 63: 489-491.

Liv Y., Zhai Y.H., Gu Z.M. 2016: Morphological and molecular characterization of Thelohanellus macrovacuolaris $\mathrm{n}$. $\mathrm{sp}$. (Myxosporea: Bivalvulida) infecting the palate in the mouth of common carp Cyprinus carpio L. in China. Parasitol. Int. 65: 303-307.

Lom J., Arthur J.R. 1989: A guideline for preparation of species descriptions in Myxosporea. J. Fish Dis. 12: 151-156.

Loм J., DyKovÁ I. 2006: Myxozoan genera: definition and notes on taxonomy, life-cycle terminology and pathogenic species. Folia Parasitol. 53: 1-36.

Mansour L., Al-Qahtani H.A., Al-Quraishy S., Abdel-BaKI A.A. 2015: Molecular and morphometric characteristics of Ceratomyxa hamour n. sp. (Myxosporea: Bivalvulida) infecting the gallbladder of the orange-spotted grouper Epinephelus coioides from the Arabian Gulf, Saudi Arabia. J. Euk. Microbiol. 62: 95-101.

Özer A., Gürkanli C.T., Özkan H., Acar G., Çıftçı Y., YURAKhno V. 2016: Molecular characterization and morphological aspects of Myxobolus parvus (Myxozoa) from Liza saliens (Mugilidae) off the Turkish Black Sea coasts. Parasitol. Res. 115: 3513-3518.

Posada D. 2008: jModelTest: phylogenetic model averaging. Mol. Biol. Evol. 25: 1253-1256.

Ronquist F., Huelsenbeck J.P. 2003: MrBayes 3: Bayesian phylogenetic inference under mixed models. Bioinformatics 19: 1572-1574

Shin S.P., Nguyen V.G., Jeong J.M., Jun J.W., Kim J.H., Jan J.E., BAeck G.W., PARK S.C. 2014: The phylogenetic study on Thelohanellus species (Myxosporea) in relation to host specificity and infection site tropism. Mol. Phyl. Evol. 72: 31-34.

Shulman S.S. 1966: [Myxosporidia of the Fauna of the USSR]. Nauka, Moscow, 504 pp. (In Russian.)

Thabet A., Mansour L., Al Omar S.Y., Tlig-Zouari S. 2016 : Ceratomyxa tunisiensis n. sp. (Myxosporea: Bivalvulida) from the gallbladders of two carangid fish caught off the coast of Tunisia. J. Eukaryot. Microbiol. 63: 86-92.

Velasco M., Videira M., Nascimento Lde C., Matos P., Goncalves E.C., Matos E. 2016: Henneguya paraensis n. sp. (Myxozoa; Myxosporea), a new gill parasite of the Amazonian fish Cichla temensis (Teleostei: Cichlidae): morphological and molecular aspects. Parasitol. Res. 115: 1779-1787.

Whipps C.M., Adlard R.D., Bryant M.S., Lester R.J., FindLAY V., Kent M.L. 2003: First report of three Kudoa species from eastern Australia: Kudoa thyrsites from Mahi mahi (Coryphaena hippurus), Kudoa amamiensis and Kudoa minithyrsites n. sp. from sweeper (Pempheris ypsilychnus). J. Euk. Microbiol. 50: 215-219. 